Review

\title{
Pharmacological Management of Spontaneous Intracerebral Hemorrhage in Older Adults
}

Melissa Sandler ${ }^{1,2}$, Sulaiman Almohaish ${ }^{1,3}$, Gretchen M. Brophy ${ }^{1,}{ }^{*}$

1. Virginia Commonwealth University, School of Pharmacy, Department of Pharmacotherapy and Outcomes Science, Richmond, Virginia, USA; E-Mails: sandlerm@vcu.edu; almohaishsm@vcu.edu; gbrophy@vcu.edu

2. Virginia Commonwealth University, Department of Physical Medicine and Rehabilitation, School of Medicine, Richmond, Virginia, USA

3. King Faisal University, College of Clinical Pharmacy, Al-Ahsa, Saudi Arabia

* Correspondence: Gretchen M. Brophy; E-Mail: gbrophy@vcu.edu

Academic Editor: David G Smithard

Special Issue: Stroke in Older Adults

OBM Geriatrics

2021, volume 5, issue 1

doi:10.21926/obm.geriatr.2101161
Received: February 11, 2021

Accepted: March 11, 2021

Published: March 16, 2021

\begin{abstract}
Pharmacological management of intracerebral hemorrhage in adult patients over 65 years of age requires special considerations due to differing clinical presentations, underlying organ dysfunction, and more complex medical histories and medication profiles. A literature review of articles focusing on the age-specific pharmacological management of intracerebral hemorrhage was conducted. Treatment approaches and clinical outcomes specific to older adults were evaluated and therapeutic considerations for this population are summarized. Older adults were commonly included in trials regarding reversal of anticoagulants and antiplatelet agents and these results are generalizable to older adults. Underlying organ dysfunction should frequently be considered throughout the treatment of intracerebral hemorrhage in older adults. Older adults with intracerebral hemorrhage should be managed
\end{abstract}

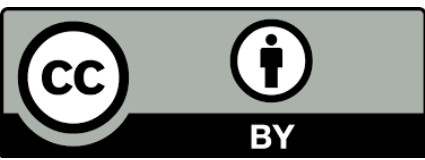

(C) 2021 by the author. This is an open access article distributed under the conditions of the Creative Commons by Attribution License, which permits unrestricted use, distribution, and reproduction in any medium or format, provided the original work is correctly cited. 
similarly to younger adult patients; however, consideration of age-related comorbidities and physiological differences is critically important for optimizing patient care.

\section{Keywords}

Intracerebral hemorrhage; stroke; older adult; treatment; pharmacology

\section{Introduction}

As the population of older adult patients (65 years and older) continues to rise, it is expected that the incidence of intracerebral hemorrhage $(\mathrm{ICH})$ will increase as well $[1,2]$. There are differences between the presentation and etiology of an $\mathrm{ICH}$ in an older adult compared to that of a younger patient, including a higher prevalence of ventricular extension of the hematoma and cerebral amyloid angiopathy in older adults [2,3]. Management of $\mathrm{ICH}$ in older adults is challenging from the initial assessment to treatment decisions due to a lack of evidence-based age-specific management strategies, and the fact that older adults may have cognitive disorders that complicate a neurological exam, complex medication regimens, and altered pharmacokinetics [4]. The current $\mathrm{ICH}$ guidelines do not specify treatment strategies for older adult patients with $\mathrm{ICH}$; however, consideration of age-related comorbidities and physiological differences is critically important for optimizing patient care.

There are three main considerations for the pharmacological management of $\mathrm{ICH}$ - hemostasis, blood pressure management, and venous thromboembolism (VTE) prophylaxis. This article will review these treatment strategies and the supporting evidence in older adults.

\section{Therapeutic Strategies for Hemostasis}

Hemostatic abnormalities due to underlying clotting disorders or daily anticoagulant or antiplatelet use contribute to the risk of $\mathrm{ICH}$ and to clinical outcomes after $\mathrm{ICH}$ [5]. One of the primary goals of $\mathrm{ICH}$ treatment is to stop active bleeding and prevent hematoma expansion by rapidly addressing these abnormalities. Patients taking oral anticoagulants have up to a ten times higher risk of developing ICH than the general population [6]. Although the risk of ICH is decreased by about $50 \%$ in patients taking direct oral anticoagulants (DOACs) compared to warfarin, patients with $\mathrm{ICH}$ who are taking any oral anticoagulant agent have worse clinical outcomes as compared to those who do not, including a 1.62 and 1.21 times higher risk of in-hospital mortality for patients on warfarin and a DOAC, respectively $[6,7]$. Antiplatelet use also increases the risk of in-hospital mortality [7]. The risk of developing a devastating $\mathrm{ICH}$ is higher if a patient is on an antiplatelet or anticoagulant and older adults are more likely to be on these medications than the general population [8].

Hemostasis can be achieved using various treatment strategies, including prothrombin complex concentrates (PCC), vitamin K, blood products including fresh frozen plasma (FFP) and platelets, tranexamic acid, desmopressin, and anticoagulant-specific reversal agents. These therapies have been used to reduce hematoma expansion and improve outcomes in patients with ICH (Table 1). Although only two of the trials reviewed provided subgroup analyses based on age, older adults were well represented in the trials and general management strategies for older patients are similar 
to those recommended in published ICH guidelines for reversal of antithrombotics (Table 2) [9]. However, ICH treatment differences do exist for drug dosing for the older adult versus the younger adult patients due to the confounding variables.

Table 1 Select intracerebral hemorrhage hemostasis clinical studies summary.

\begin{tabular}{|c|c|c|c|c|}
\hline & Interventions & $\begin{array}{l}\text { Age } \\
\text { (years) }\end{array}$ & Prima & Age-related results \\
\hline $\begin{array}{l}\text { Mayer, et al. } \\
\text { (FAST) } \\
N=841\end{array}$ & $\begin{array}{l}\text { rFVIla vs placebo } \\
\text { for ICH }\end{array}$ & $\begin{array}{l}\text { Mean } 65 \\
\pm \quad 14 \\
\text { (range } \\
23-97 \text { ) }\end{array}$ & $\begin{array}{l}\mathrm{mRS}>4 \text { at } 90 \text { days: } \\
24 \% \text { in placebo, } 26 \% \text { in } \\
20 \mathrm{mcg} / \mathrm{kg}, 29 \% \text { in } 80 \\
\mathrm{mcg} / \mathrm{kg}, \mathrm{p}>0.05\end{array}$ & $\begin{array}{l}\text { Age a risk factor for } \\
\text { thromboembolic serious } \\
\text { adverse events, OR } 1.1(95 \% \\
\mathrm{Cl}, 1-1.2) \text { per } 5 \text { years, } \mathrm{p}=0.02\end{array}$ \\
\hline $\begin{array}{l}\text { Diringer, et al. } \\
{[11]} \\
N=841\end{array}$ & $\begin{array}{l}\text { rFVIla vs placebo } \\
\text { for ICH }\end{array}$ & $\begin{array}{l}\text { Mean } 65 \\
\pm \quad 14 \\
\text { (range } \\
23-97 \text { ) }\end{array}$ & $\begin{array}{l}\text { Venous } \\
\text { thromboembolism: } \\
6 \% \text { in placebo, } 5 \% \text { in } 20 \\
\mathrm{mcg} / \mathrm{kg}, 5 \% \text { in } 80 \\
\mathrm{mcg} / \mathrm{kg}, \mathrm{p}>0.05\end{array}$ & 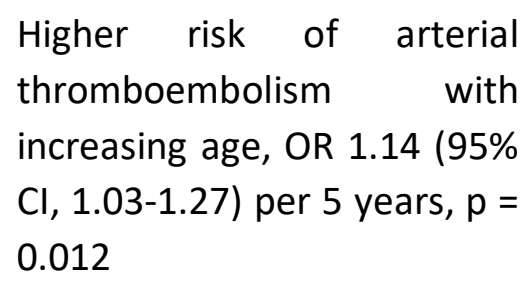 \\
\hline $\begin{array}{l}\text { Steiner, et al. } \\
(\text { INCH) } \\
N=50\end{array}$ & $\begin{array}{l}\text { FFP vs } 4 F-P C C \text { for } \\
\text { warfarin } \\
\text { associated } \quad I C H \\
\text { and INR } \geq 2\end{array}$ & $\begin{array}{l}\text { Mean } \\
75.6\end{array}$ & $\begin{array}{l}\text { INR } \leq 1.2 \text { within } 3 \mathrm{hrs} \text { of } \\
\text { treatment: } \\
9 \% \text { vs } 67 \%, p=0.003\end{array}$ & None \\
\hline $\begin{array}{l}\text { Baharoglu, et } \\
\text { al. (PATCH) [13] } \\
N=190 \\
>80 \text { years, } n=62\end{array}$ & $\begin{array}{l}\text { Platelet } \\
\text { transfusion vs } \\
\text { standard of care } \\
\text { for antiplatelet } \\
\text { associated ICH }\end{array}$ & $\begin{array}{l}\text { Mean } \\
73.8 \\
\text { (range } \\
40-94 \text { ) }\end{array}$ & $\begin{array}{l}\text { mRS shift at } 3 \text { months: } \\
\text { OR } 2.05(1.18-3.56), p= \\
0.0114\end{array}$ & None \\
\hline $\begin{array}{l}\text { Glund, et al. } \\
{[14]} \\
N=28 \\
65-80 \quad \text { years, } \\
n=16\end{array}$ & $\begin{array}{l}\text { Idarucizumab (no } \\
\text { control) for } \\
\text { dabigatran in } \\
\text { healthy adults }\end{array}$ & $\begin{array}{l}\text { Mean } 69 \\
\text { among } \\
\text { elderly } \\
\text { group }\end{array}$ & $\begin{array}{l}\text { Mild or moderate renal } \\
\text { impairment increased } \\
\text { exposure, decreased } \\
\text { clearance, and } \\
\text { prolonged half-life }\end{array}$ & $\begin{array}{l}\text { No significant difference in } \\
\text { AUC, half-life, total clearance, } \\
\text { or plasma concentration }\end{array}$ \\
\hline $\begin{array}{l}\text { Pollack, et al. } \\
\text { (RE-VERSE AD) } \\
{[15]} \\
\mathrm{N}=503 \\
\mathrm{ICH}, \mathrm{n}=98\end{array}$ & $\begin{array}{l}\text { Idarucizumab (no } \\
\text { control) for } \\
\text { dabigatran } \\
\text { associated } \\
\text { bleeding }\end{array}$ & $\begin{array}{l}\text { Median } \\
78 \\
\text { (range } \\
21-96 \text { ) }\end{array}$ & $\begin{array}{l}\text { Percentage of reversal } \\
\text { of anticoagulant effect } \\
\text { within } 4 \text { hrs: } 100 \%\end{array}$ & $\begin{array}{l}\text { "Reversal... occurred } \\
\text { independently of age..." - no } \\
\text { further details }\end{array}$ \\
\hline 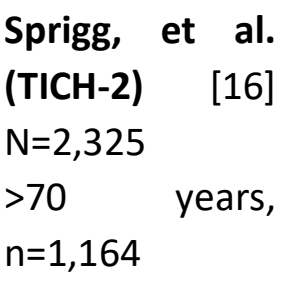 & $\begin{array}{l}\text { TXA vs placebo } \\
\text { for } \mathrm{ICH}\end{array}$ & $\begin{array}{l}\text { Mean } \\
68.9 \quad \pm \\
13.8 \\
\text { (range } \\
20-101 \text { ) }\end{array}$ & $\begin{array}{l}\text { mRS shift at day 90: } \\
\text { OR } 0.99(0.76-1.03), p= \\
0.11\end{array}$ & $\begin{array}{l}\text { Prespecified subgroup for } \\
\text { functional status at } 90 \text { days: } \\
\leq 70 \text { : OR } 0.84(0.68-1.04) \\
>70 \text { : OR } 0.96(0.77-1.19)\end{array}$ \\
\hline
\end{tabular}




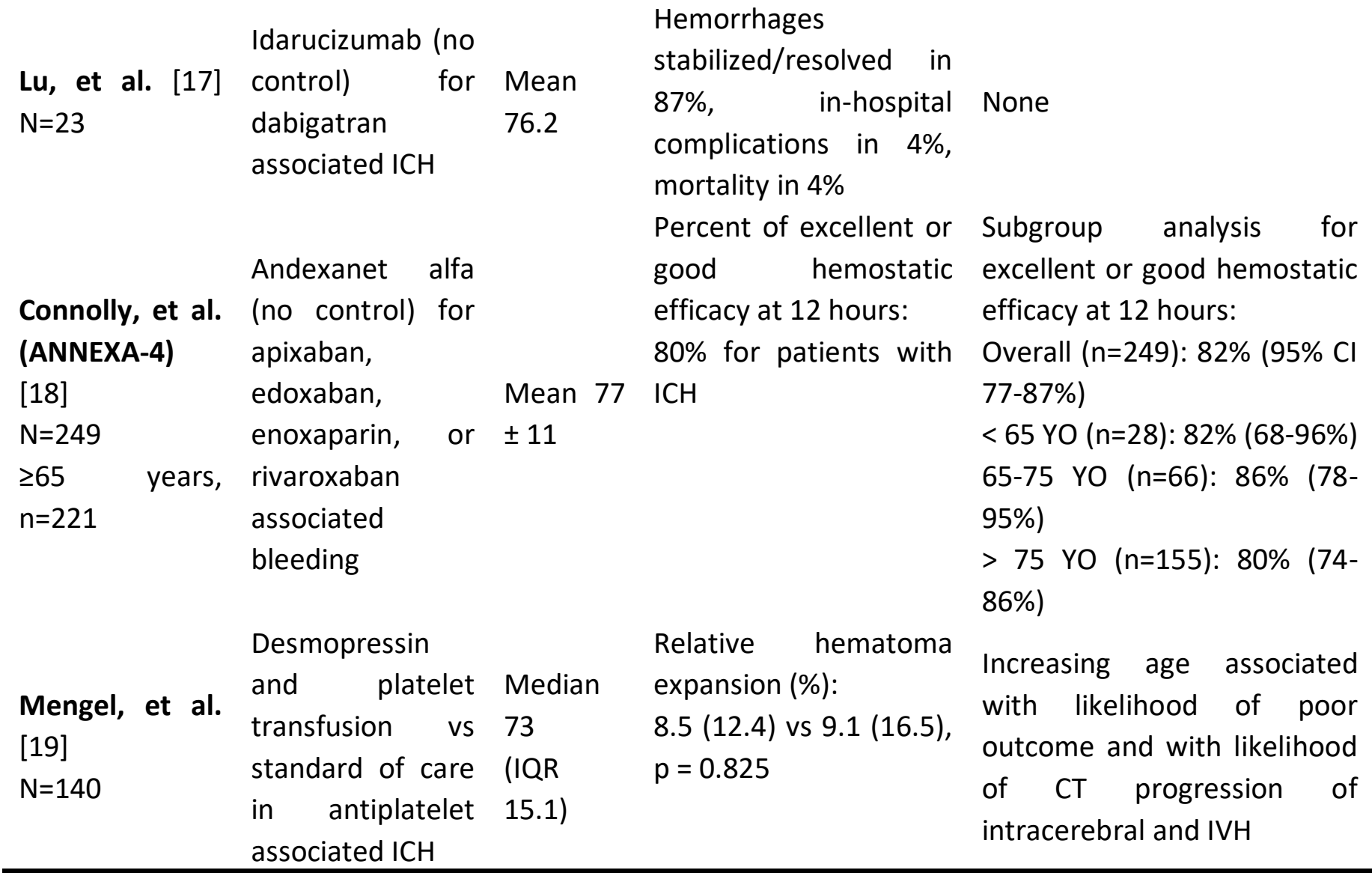

4F-PCC - four factor prothrombin complex concentrate; AUC - area under the concentrationtime curve; CT - computed tomography; FFP - fresh frozen plasma; ICH - intracerebral hemorrhage; IQR - interquartile range; IVH - intraventricular hemorrhage; mRS - modified Rankin scale; OR - odds ratio; rFVIla - recombinant factor VII; TXA - tranexamic acid; YO - years old

Table 2 Guideline recommendations for the reversal of antiplatelet and anticoagulants in patients with intracerebral hemorrhage [9].

\begin{tabular}{|c|c|c|}
\hline Home Medication & & Recommendation \\
\hline \multirow{3}{*}{ Antiplatelet } & Aspirin & Consider DDAVP $0.4 \mathrm{mcg} / \mathrm{kg} \mathrm{IV}$ \\
\hline & P2Y12 inhibitors & No platelet transfusion if no planned neurosurgical procedure \\
\hline & Warfarin & $\begin{array}{l}\text { If INR } \geq 1.4 \text {, vitamin } \mathrm{K} 10 \mathrm{mg} \text { IV + 3- or 4-factor PCC (suggest 4- } \\
\text { factor preferred) }\end{array}$ \\
\hline \multirow[t]{2}{*}{ Anticoagulant } & $\begin{array}{l}\text { Apixaban, } \\
\text { edoxaban, } \\
\text { rivaroxaban* }\end{array}$ & $\begin{array}{l}\text { Activated charcoal } 50 \text { grams if within } 2 \text { hours of ingestion }+ \\
\text { activated or 4-factor PCC if within 3-5 half-lives of drug* }\end{array}$ \\
\hline & Dabigatran & $\begin{array}{l}\text { Activated charcoal } 50 \text { grams if within } 2 \text { hours of ingestion }+ \\
\text { idarucizumab } 5 \text { grams IV or hemodialysis if idarucizumab } \\
\text { unavailable }\end{array}$ \\
\hline
\end{tabular}

DDAVP - desmopressin; INR - international normalized ratio; IV - intravenous; PCC prothrombin complex concentrate

*These guidelines were developed prior to the availability of andexanet alfa. 
Treatment considerations for older adults with ICH include more complex medical histories, polypharmacy, decreased renal and hepatic function, and goals of care. When an older adult presents with $\mathrm{ICH}$, home antiplatelet and anticoagulant medications should be highly suspected. A thorough medication history should be performed by interrogating the patient (if possible), family members, and the outpatient and inpatient electronic medical records, as this information may drastically alter the patient's ICH treatment strategy.

Complicated medical histories are generally accompanied by complex medication regimens, especially in older adult patients [20]. Therefore, when reviewing home medication lists, drug interactions with anticoagulant and antiplatelet agents that may increase and prolong the effects of these agents should be suspected and addressed upon admission and at discharge.

Cardiac, renal, and hepatic function must also be considered in older adults with ICH. Organ dysfunction can decrease elimination of anticoagulants and antiplatelet agents and will decrease drug clearance and extend the pharmacodynamic monitoring window for these agents. Doses of discharge medications should be properly adjusted based on organ function and drug interactions to prevent excessive anticoagulant effects and recurrent $\mathrm{ICH}$.

Once ICH is controlled, the timing of anticoagulation or antiplatelet resumption is highly debated $[5,21]$. For older adults with more complex medical histories, the indication for anticoagulation must be considered. A mechanical heart valve or a recent cardiac stent, for example, would be reasons for restarting home anticoagulation or antiplatelet agents sooner (e.g. 7-10 days) versus later (e.g. 4-6 weeks).

Table 1 summarizes the representation of older adults in select hemostasis trials. Except for the special considerations discussed above, $\mathrm{ICH}$ management is similar for younger and older adults (Table 2).

\subsection{Anticoagulant Reversal}

Anticoagulants increase the risk of $\mathrm{ICH}$ and poor outcomes in both older and younger adult patients $[5,6]$. The oral anticoagulants that patients are prescribed in the outpatient setting include vitamin $\mathrm{K}$ antagonists and DOACs.

Warfarin is a vitamin $\mathrm{K}$ antagonist with a long half-life of about one week. Because it is an older drug, it has the most data regarding reversal of its anticoagulant effect. Vitamin $\mathrm{K}$ is always recommended as part of the reversal strategy for warfarin as the replacement of vitamin $\mathrm{K}$ is needed to reverse the effects of warfarin over time. A more recent study, the international normalized ratio (INR) normalization in coumadin-associated intracranial hemorrhages trial (INCH), established fourfactor PCC as superior to FFP for the reversal of warfarin-associated ICH [12]. Therefore, for warfarin-associated ICH, both intravenous vitamin $\mathrm{K}$ and $\mathrm{PCC}$ are recommended (Table 2) [9].

Direct oral anticoagulants consist of dabigatran, a direct thrombin inhibitor, and anti-Xa inhibitors (e.g., apixaban, edoxaban, rivaroxaban, and betrixaban). Idarucizumab, a monoclonal antibody that binds dabigatran was established as a rapid, durable, and safe reversal agent in the study of the reversal effects of idarucizumab on active dabigatran trial (RE-VERSE AD) [15].

As for the anti-Xa agents, the ideal agent for reversal is still controversial. Andexanet alfa is approved for anti-Xa inhibitor reversal with a mechanism of action of binding and sequestering anti$\mathrm{Xa}$ inhibitors. Although shown to be effective in reducing factor Xa activity, andexanet alfa has not been universally accepted due to the limited data on superiority to PCCs, which was the only agent 
clinically effective and available for use prior to the availability of andexanet alfa, and andexanet alfa's high cost [18].

Drug interactions due to CYP enzyme induction or inhibition need to be considered as all the oral anticoagulants, except dabigatran, are metabolized by CYP3A4 and other CYP enzymes. All the DOACs are p-glycoprotein (P-gp) substrates so drug interactions with this pathway should be considered as well [22]. Dietary intake of vitamin $\mathrm{K}$ containing foods and antibiotic reductions in vitamin $\mathrm{K}$ producing gut bacteria must also be considered in patients receiving warfarin.

Apixaban, edoxaban, and rivaroxaban are recommended to be reversed with andexanet alfa or PCC when the last dose has been taken with 3-5 half-lives of the drug [9]. All of the new oral anticoagulants require renal dose adjustments, which is likely necessary for those with advanced age [22]. In patients with severe renal dysfunction, the half-lives of these medications can be increased by as much as double (Table 3) [23, 24]. Considering the high cost of these newer drugspecific reversal agents, the time of the last dose of an anticoagulant should be determined, if possible, prior to administration. As for blood products such as FFP, renal function and cardiac function should be monitored due to the large fluid volumes associated with these products. Compared to FFP, PCC delivers significantly less fluid volume (approximately $90 \mathrm{~mL}$ vs $800 \mathrm{~mL}$ ) and is associated with less clinical volume overload (4.7\% vs $12.7 \%$ ) [25].

Table 3 Pharmacokinetics of oral anticoagulants [23].

\begin{tabular}{llllll}
\hline & $\begin{array}{l}\text { \% Renally } \\
\text { Eliminated } \\
\text { Unchanged }\end{array}$ & $\begin{array}{l}\mathrm{T}_{\mathbf{1 / 2}} \\
\text { (hours) }\end{array}$ & $\begin{array}{l}\mathrm{T}_{\mathbf{1 / 2}} \text { with } \\
\text { renal } \\
\text { (hours) }\end{array}$ & $\begin{array}{l}\text { moderate } \\
\text { dysfunction }\end{array}$ & $\begin{array}{l}\mathrm{T}_{\mathbf{1} 2 \mathbf{2}} \text { with severe renal } \\
\text { dysfunction (hours) }\end{array}$ \\
\hline Apixaban & 27 & 15.1 & 17.6 & 17.3 \\
Betrixaban & 11 & $19-27$ & Unknown & Unknown \\
Dabigatran & 80 & 13.8 & 18.7 & 27.5 \\
Edoxaban & 50 & 8.6 & 9.4 & 16.9 \\
Rivaroxaban & 33 & 8.3 & 9 & 9.5 \\
\hline
\end{tabular}

\subsection{Antiplatelet Reversal}

The impact of antiplatelet agents on hematoma expansion and functional outcome is less clear than that of anticoagulant agents [7, 9] Older adult patients may be on single or dual antiplatelet therapy for a variety of indications including prior stroke, myocardial infarction, peripheral artery disease, or for primary prevention of these conditions. Unlike with anticoagulants, there are no reversal agents that bind antiplatelet agents. Platelet transfusions aim to replace hindered platelets that are bound by antiplatelet agents, while desmopressin attempts to cause a release of von Willebrand factor to induce platelet adhesion [9]. Platelet infusions have been demonstrated to cause harm in an antiplatelet-associated ICH trial in which a majority of patients received aspirin and older adults were well represented [13]. In vitro studies have demonstrated that platelet transfusions are less effective in reversing the effects of ticagrelor as it and its active metabolite are still available to affect platelet aggregation after the transfusion is completed. This study concluded that platelet infusions may not be effective in reversing ticagrelor until 24 hours after the last dose [26]. More trials are required to confirm this observation. Overall, platelet transfusions have been determined to be ineffective or even to cause harm in patients with antiplatelet-associated ICH and 
are not recommended, except for patients undergoing surgery. Similarly, a retrospective review of patients with antiplatelet associated $\mathrm{ICH}$ receiving desmopressin and a platelet transfusion demonstrated no benefit to either platelet transfusion or desmopressin for this indication [19].

In addition to a lack of specific reversal agents for antiplatelet agents, there are no specific recommendations for older adults presenting with antiplatelet-associated ICH. Physiologically, older adults are likely to have reduced renal and hepatic function and this can impact drug concentrations and effects. Renal and hepatic function have a limited role when estimating the halflife of antiplatelet agents because most agents (except ticagrelor) bind platelets irreversibly and therefore are active for the lifespan of a platelet (8-20 days). Renal function does not impact the duration of action of ticagrelor, but mild hepatic impairment increases drug exposure due to its extensive liver metabolism [9, 27].

\subsection{Other Hemostatic Agents}

Hemostatic agents are generally not recommended for spontaneous $\mathrm{ICH}$, but do have use in specific situations [5, 9]. Tranexamic acid and aminocaproic acid which inhibit fibrin degradation by inhibiting the conversion of plasminogen to plasmin are suggested to be used for thrombolytic (i.e., alteplase, tenecteplase) associated $\mathrm{ICH}$, but cryoprecipitate is recommended as first line treatment [28]. Recombinant factor VIIa ( $\mathrm{rFVIIa)} \mathrm{is} \mathrm{recommended} \mathrm{for} \mathrm{low-molecular-weight} \mathrm{heparin} \mathrm{associated}$ $\mathrm{ICH}$ if protamine is contraindicated [9].

\section{Blood Pressure Management}

Cerebral amyloid angiopathy is one of the more common etiologies of $\mathrm{ICH}$ in older adults. However, long-standing, uncontrolled hypertension is also a common cause of $\mathrm{ICH}$, especially in developing countries, with high systolic blood pressures associated with worse outcomes [2, 5, 29]. The ideal target blood pressure for a patient with $\mathrm{ICH}$ is not known and has been the subject of many trials (Table 4). Guidelines have suggested goals for blood pressure control and are summarized in Table 5. However, these goals are still controversial. Based on available evidence, rapidly reducing blood pressure to $140-150 \mathrm{mmHg}$ may likely balance the risk of hemorrhage expansion and cerebral autoregulation issues, although patients with higher presenting blood pressure (i.e. $\geq 180 \mathrm{mmHg}$ ) may have a greater risk of renal injury [30-35]. Knowledge of the patient's pre-ICH baseline blood pressures readings as well as frequent neurological assessments during hospitalization may help guide antihypertensive therapy and avoid further complications in the acute setting.

Table 4 Blood pressure management clinical studies summary.

\begin{tabular}{|c|c|c|c|c|}
\hline & Interventions & $\begin{array}{l}\text { Age } \\
\text { (years)* }\end{array}$ & $\begin{array}{l}\text { Primary } \\
\text { Outcome }\end{array}$ & Age-related results \\
\hline 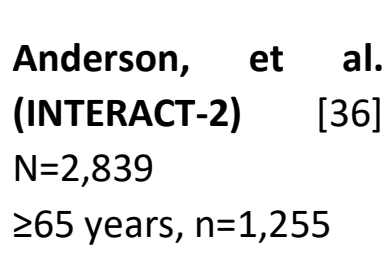 & $\begin{array}{l}\text { SBP goal }<140 \\
\mathrm{mmHg} \text { vs }<180 \\
\mathrm{mmHg} \text { for } 7 \text { days } \\
\text { in ICH }\end{array}$ & $\begin{array}{l}\text { Mean } \\
63.5\end{array}$ & $\begin{array}{l}\mathrm{mRS} \geq 3 \text { at } 90 \\
\text { days: } \\
52 \text { vs } 55.6 \%, p \\
=0.06\end{array}$ & $\begin{array}{l}\text { Subgroup analysis for death } \\
\text { or major disability at } 90 \\
\text { days: } \\
<65 \text { YO ( } n=1,539) \text { : OR } 0.87 \\
(0.71-1.06)\end{array}$ \\
\hline
\end{tabular}


$\geq 65$ YO $(n=1,255)$ : OR 0.91

(0.72-1.15)

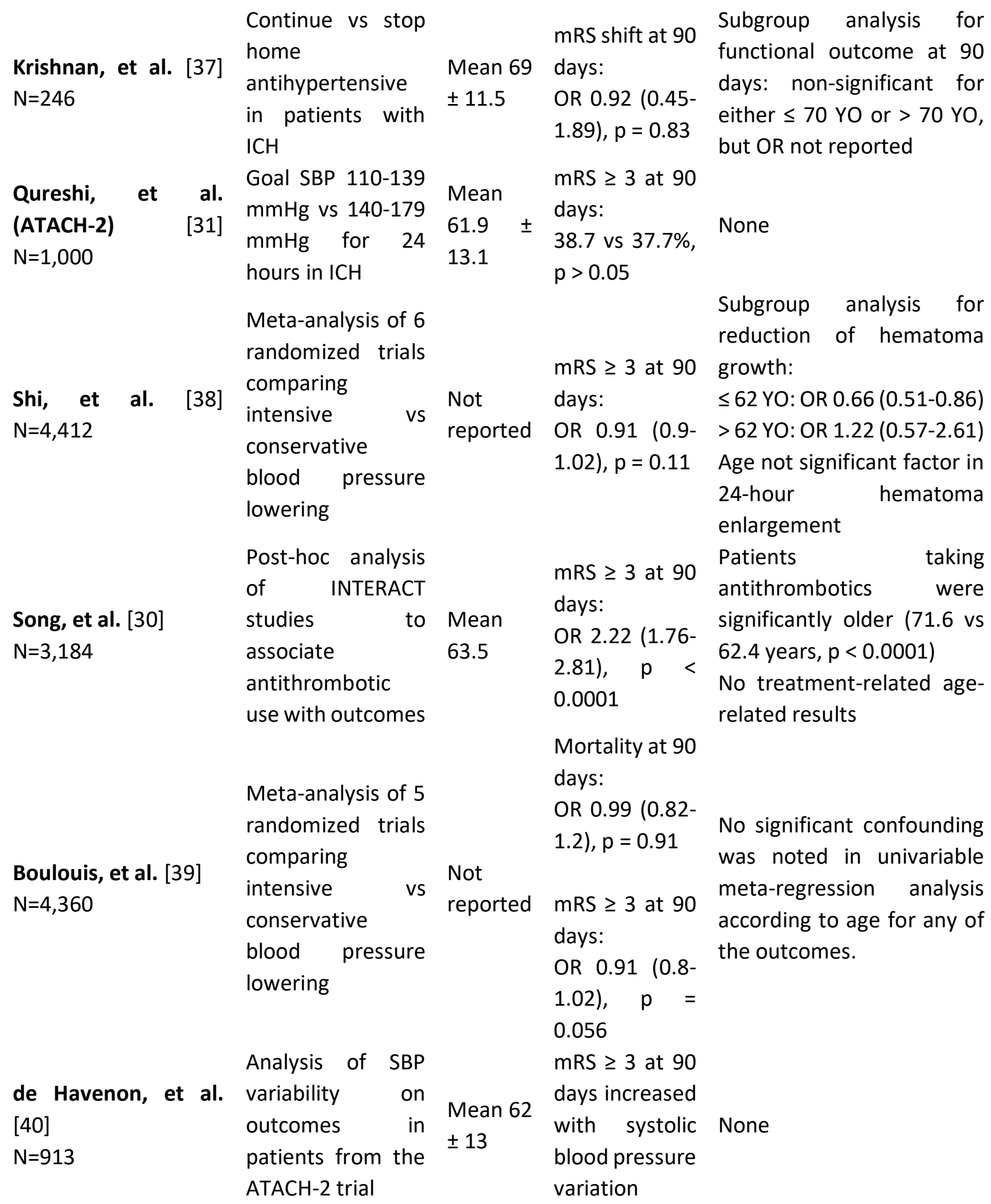




\begin{tabular}{|c|c|c|c|c|}
\hline \multirow{4}{*}{$\begin{array}{l}\text { Divani, et al. [41] } \\
N=757\end{array}$} & \multirow{5}{*}{$\begin{array}{l}\text { Retrospective } \\
\text { review to assess } \\
\text { magnitude of SBP } \\
\text { reduction on } \\
\text { outcomes in ICH }\end{array}$} & \multirow{4}{*}{$\begin{array}{l}\text { Median } \\
65 \\
\text { (IQR 23) }\end{array}$} & Each $10 \mathrm{mmHg}$ & \multirow{4}{*}{$\begin{array}{l}\text { Older patients were more } \\
\text { likely to have poor } \\
\text { functional outcome at } \\
\text { discharge } \\
\text { No treatment-related age- } \\
\text { related results }\end{array}$} \\
\hline & & & $\begin{array}{l}\text { in blood } \\
\text { pressure } \\
\text { reduction } \\
\text { associated }\end{array}$ & \\
\hline & & & $\begin{array}{l}\text { with } \mathrm{mRS} \geq 3 \text { : } \\
\text { OR } 1.13 \text { (1.04- }\end{array}$ & \\
\hline & & & 1.23), $\quad \mathrm{p}=$ & \\
\hline & & & 0.003 & \\
\hline
\end{tabular}

$\mathrm{ICH}$ - intracerebral hemorrhage; IQR - interquartile range; $\mathrm{MI}$ - myocardial infarction; mRS modified Rankin scale; OR - odds ratio; SBP - systolic blood pressure; YO - years old; *Mean \pm SD unless otherwise notes

Table 5 Guideline recommendations for acute blood pressure management in patients with intracerebral hemorrhage.

\begin{tabular}{|c|c|c|}
\hline $\begin{array}{l}\text { Presenting } \\
\text { Pressure }\end{array}$ & 2015 AHA/ASA Guideline [5] & 2017 ACC/AHA Guideline [29] \\
\hline SBP $150-220 \mathrm{mmHg}$ & $\begin{array}{l}\mathrm{SBP}<140 \mathrm{mmHg} \text { is safe and can } \\
\text { improve functional outcome }\end{array}$ & $\begin{array}{l}\text { Immediate lowering of SBP to }<140 \mathrm{mmHg} \\
\text { is not beneficial and can be harmful }\end{array}$ \\
\hline SBP >220 mmHg & $\begin{array}{l}\text { Reasonable to consider aggressive } \\
\text { reduction }\end{array}$ & $\begin{array}{l}\text { Reasonable to use continuous IV drugs to } \\
\text { lower SBP }\end{array}$ \\
\hline
\end{tabular}

Titratable antihypertensive agents and considerations for older adults are summarized in Table 6 [29]. Drugs eliminated by plasma esterases (i.e., clevidipine, esmolol) will not accumulate in patients with organ dysfunction whereas drug eliminated renally or hepatically may accumulate and cause hypotension. As with all patients, drugs with a faster onset and shorter duration of action may prevent premature escalations in dose causing precipitous drops in blood pressure. For example, clevidipine has a shorter onset and duration of action than nicardipine and therefore may be preferred in older adults. Nitroprusside is an option for blood pressure management, but generally should be avoided due to multiple safety concerns. For patients with a recent history of myocardial infarction, nitroprusside should not be used as it diverts blood from the coronary vessels. Additionally, special attention should be given to nitroprusside if it must be used in patients with renal dysfunction as toxic metabolites may accumulate. In general, older adults should be treated with lower doses and titrated more slowly.

Table 6 Titratable antihypertensive medications commonly used for intracerebral hemorrhage.

\begin{tabular}{llll}
\hline & $\begin{array}{l}\text { Mechanism of } \\
\text { Action and Dose }\end{array}$ & Metabolism & Other Considerations \\
\hline Clevidipine & Calcium channel & Plasma & First line agent \\
& blocker & esterase & Very rapid onset and offset \\
& $1-2 \mathrm{mg} / \mathrm{hour} \mathrm{CIVI}$, & & Fat emulsion, contraindicated in soy or egg allergy \\
& & Start with lower doses for older adults
\end{tabular}




\begin{tabular}{|c|c|c|c|}
\hline Diltiazem & $\begin{array}{l}\text { Calcium channel } \\
\text { blocker } \\
5 \mathrm{mg} / \text { hour CIVI, max } \\
15 \mathrm{mg} / \text { hour }\end{array}$ & Hepatic & $\begin{array}{l}\text { Bradycardia } \\
\text { Drug-drug interactions possible }\end{array}$ \\
\hline Hydralazine & $\begin{array}{l}\text { Arterial dilator } \\
10-20 \mathrm{mg} \text { IV bolus }\end{array}$ & Hepatic & $\begin{array}{l}\text { Longest onset of action and variable duration; } \\
\text { therefore, not a first line agent }\end{array}$ \\
\hline Labetalol & $\begin{array}{l}\text { Mixed alpha and } \\
\text { beta antagonist } \\
10-20 \mathrm{mg} \text { IV over } 1- \\
2 \text { minutes or } \\
0.5-1 \mathrm{mg} / \mathrm{kg} / \text { hour } \\
\mathrm{CIVI}, \mathrm{max} 3 \\
\mathrm{mg} / \mathrm{kg} / \text { hour }\end{array}$ & Hepatic & $\begin{array}{l}\text { First line agent } \\
\text { Longer onset of action and duration } \\
\text { Bradycardia } \\
\text { Caution in heart failure }\end{array}$ \\
\hline Nicardipine & $\begin{array}{l}\text { Calcium channel } \\
\text { blocker } \\
2.5-5 \mathrm{mg} / \text { hour CIVI, } \\
\max 15 \mathrm{mg} / \text { hour }\end{array}$ & Hepatic & $\begin{array}{l}\text { First line agent } \\
\text { Triphasic elimination (can accumulate over time) } \\
\text { No dose adjustment needed for older adults } \\
\text { Drug-drug interactions possible }\end{array}$ \\
\hline Nitroglycerin & $\begin{array}{l}\text { Venodilation } \\
5 \mathrm{mcg} / \mathrm{min} \mathrm{CIVI}, \max \\
20 \mathrm{mcg} / \mathrm{min}\end{array}$ & Hepatic & $\begin{array}{l}\text { Tachyphylaxis } \\
\text { Decreases cardiac output } \\
\text { May cause headache }\end{array}$ \\
\hline Nitroprusside & $\begin{array}{l}\text { Arterial and } \\
\text { venodilation } \\
0.25-0.5 \\
\mathrm{mcg} / \mathrm{kg} / \mathrm{min} \mathrm{ClVI} \\
\mathrm{max} 10 \mathrm{mcg} / \mathrm{kg} / \mathrm{min}\end{array}$ & Renal & $\begin{array}{l}\text { Cyanide/thiocyanate toxicity in renal dysfunction } \\
\text { Tachyphylaxis } \\
\text { May increase intracranial pressure with }>0.25 \\
\mathrm{mcg} / \mathrm{kg} / \mathrm{min} \text { rapid dosage adjustments } \\
\text { May cause coronary steal } \\
\text { Start with lower doses for older adults } \\
\text { Not recommended first line }\end{array}$ \\
\hline
\end{tabular}

$\mathrm{CIVI}$ - continuous IV infusion; min - minute

As well-defined blood pressure goals have not yet been established for $\mathrm{ICH}$, other approaches to blood pressure management are under review including magnitude of blood pressure lowering and systolic blood pressure variability $[40,41]$. Blood pressure variability has been independently associated with neurological deterioration and unfavorable outcome ( $m R S \geq 3$ ) at 3 months after $\mathrm{ICH}[42,43]$. Age specific results are not yet available for these monitoring parameters. Pretreatment blood pressure should be considered prior to determining an absolute blood pressure goal. Among patients with $\mathrm{ICH}$ and a presenting systolic blood pressure of $\geq 220 \mathrm{mmHg}$, intensive blood pressure lowering resulted in more neurological deterioration and kidney serious adverse events than standard systolic blood pressure lowering [44]. For all patients, the goal should be to prevent large fluctuations in blood pressure and frequent neurological assessments should be utilized to individualize therapy.

\section{Venous Thromboembolism (VTE) Prophylaxis}

The rates of symptomatic deep vein thrombosis and pulmonary embolism in patients with ICH are $1-2 \%$ and $0.5-2 \%$, respectively, and possibly even higher in older adults with $\mathrm{ICH}[5,45,46]$. 
Older adult patients are more likely to experience more severe symptoms associated with a VTE, but are also more likely to experience bleeding associated with prophylaxis [45]. Which therapy is preferred and when to start this intervention is not well established in any adult patient with $\mathrm{ICH}$, but is even less well defined for older adults (Table 7, Table 8).

Table 7 Venous thromboembolism prophylaxis clinical studies summary.

\begin{tabular}{|c|c|c|c|c|}
\hline & Interventions & $\begin{array}{l}\text { Age } \\
\text { (years) }\end{array}$ & Primary Outcome & Age-related results \\
\hline $\begin{array}{l}\text { Dennis, et al. } \\
\text { (CLOTS 1) [47] } \\
\mathrm{N}=2,518 \\
\mathrm{ICH}, \mathrm{n}=232\end{array}$ & $\begin{array}{l}\text { Thigh-length } \\
\text { graduated } \\
\text { compression } \\
\text { stockings vs } \\
\text { standard of care in } \\
\text { acute stroke }\end{array}$ & $\begin{array}{l}\text { Median } \\
76 \\
\text { (IQR 68- } \\
83)\end{array}$ & $\begin{array}{l}\text { DVT in popliteal or } \\
\text { femoral veins at } 30 \\
\text { days: } \\
10 \text { vs } 10.5 \%, p>0.01\end{array}$ & None \\
\hline $\begin{array}{l}\text { Dennis, et al. } \\
\text { (CLOTS 2) [48] } \\
\mathrm{N}=3,114 \\
\mathrm{ICH}, \mathrm{n}=364\end{array}$ & $\begin{array}{l}\text { Thigh-length vs } \\
\text { below-knee } \\
\text { graduated } \\
\text { compression } \\
\text { stockings in } \\
\text { immobile stroke } \\
\text { patients }\end{array}$ & $\begin{array}{l}\text { Median } \\
\text { age } 76 \\
\text { (range } \\
67-83 \text { ) }\end{array}$ & $\begin{array}{l}\text { DVT in popliteal or } \\
\text { femoral veins at } 30 \\
\text { days: } \\
6.3 \text { vs } 8.8 \%, p=0.008\end{array}$ & None \\
\hline $\begin{array}{l}\text { Paciaroni, et al. } \\
{[49]} \\
N=1,000\end{array}$ & $\begin{array}{l}\text { Meta-analysis of } 4 \\
\text { studies comparing } \\
\text { anticoagulants vs } \\
\text { treatment other } \\
\text { than anticoagulant }\end{array}$ & $\begin{array}{l}\text { Not } \\
\text { reported }\end{array}$ & $\begin{array}{l}\text { PE: } 1.7 \text { vs } 2.9 \%, p=0.01 \\
\text { DVT: } 4.2 \text { vs } 3.3 \%, p= \\
0.36 \\
\text { Hematoma } \\
\text { enlargement: } 8 \text { vs } 4 \% \text {, } \\
p=0.45\end{array}$ & None \\
\hline 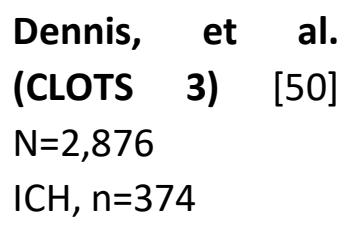 & $\begin{array}{l}\text { Intermittent } \\
\text { pneumatic } \\
\text { compression vs } \\
\text { standard of care }\end{array}$ & $\begin{array}{l}\text { Median } \\
\text { age } 76 \\
\text { (IQR } 67- \\
84)\end{array}$ & $\begin{array}{l}\text { DVT in popliteal or } \\
\text { femoral veins at } 30 \\
\text { days: } \\
8.5 \text { vs } 12.1 \%, p=0.001\end{array}$ & None \\
\hline $\begin{array}{l}\text { Farr, et al. [51] } \\
N=94\end{array}$ & $\begin{array}{l}\text { Retrospective } \\
\text { review of patients } \\
\text { with ICH that } \\
\begin{array}{l}\text { received } \\
\text { prophylaxis }\end{array}\end{array}$ & $\begin{array}{l}\text { Mean } \\
53.4 \quad \pm \\
20.5 \\
\text { (range } \\
18-87 \text { ) }\end{array}$ & $\begin{array}{l}\text { No difference in ICU } \\
(p=0.63) \text { or hospital } \\
(0.40) \text { length of stay } \\
\text { between } \\
\text { unfractionated heparin } \\
\text { and low-molecular- } \\
\text { weight heparin }\end{array}$ & None \\
\hline $\begin{array}{l}\text { Munoz-Venturelli, } \\
\text { et al. [52] } \\
N=744\end{array}$ & $\begin{array}{lr}\text { Propensity } & \text { score- } \\
\text { matched } & \\
\text { comparison } & \text { of } \\
\text { heparin } & \text { VTE } \\
\text { prophylaxis } & \text { during }\end{array}$ & $\begin{array}{l}\text { Mean } \\
65.6\end{array}$ & $\begin{array}{l}\mathrm{mRS} \geq 3 \text { at } 90 \text { days: } \\
69 \text { vs } 50 \%, p<0.001\end{array}$ & None \\
\hline
\end{tabular}


first 7 days after $\mathrm{ICH}$

versus $>7$ days

Cohort study of

Shah, et al. [53]

$\mathrm{N}=500$

Faust, et al. [54] $\mathrm{N}=400$

Sprügel, et al. [55] $\mathrm{N}=2,724$ participants

III

comparing heparin

prophylaxis within 7

days of ICH or after

Early vs late (> 48

hours after

admission) initiation

of VTE prophylaxis in

patients with $\mathrm{ICH}$

Retrospective

cohort study of

patients with $\mathrm{ICH}$ Not

who received reported

heparin for VTE

prophylaxis
Factors associated with

VTE: infection within

Mean first 30 days and no

58.6 initiation of VTE prophylaxis before VTE detection

Rebleeding: 5.6 vs $5 \%$,

Mean $p=0.8$

VTE: 0.7 vs $3.1 \%, p=$ None

0.17

ICH complications:

Subgroup analysis for risk of

$1.9 \%$ in warfarin $\mathrm{ICH}$ complications in related $\mathrm{ICH}, 0.8 \%$ in patients on heparin for VTE DOAC related $\mathrm{ICH}$, prophylaxis:

$1.6 \%$ in non- <68 YO: OR $1.41(0.63-3.14)$

anticoagulation ICH, p < 75 YO: OR 0.87 (0.35-2.14)

$=0.645$

DVT - deep vein thrombosis; ICH - intracerebral hemorrhage; ICU - intensive care unit; IQR interquartile range; $\mathrm{mRS}$ - modified Rankin scale; OR - odds ratio; PE - pulmonary embolism; VTE - venous thromboembolism; YO - years old

Table 8 Guideline recommendations for venous thromboembolism prophylaxis in patients with intracerebral hemorrhage.

\begin{tabular}{lll}
\hline & AHA/ASA Guidelines [5] & \multicolumn{2}{l}{ Neurocritical Care Guidelines [56] } \\
\hline Mechanical prophylaxis & IPC at hospital admission & $\begin{array}{l}\text { IPC and/or GPC at hospital } \\
\text { admission }\end{array}$ \\
$\begin{array}{ll}\text { Pharmacological } \\
\text { prophylaxis }\end{array}$ & $\begin{array}{l}\text { LMWH or UFH 1-4 days from LMWH or UFH within } 48 \text { hours of } \\
\text { event }\end{array}$ & \begin{tabular}{l} 
event \\
\hline
\end{tabular}
\end{tabular}

GCS - graduated compression stockings; IPC - intermittent pneumatic compression devices;

LMWH - low-molecular-weight heparin; UFH - unfractionated heparin.

Both heparin and low-molecular-weight heparins work by inactivating thrombin and factor Xa through enhancing anti-thrombin activity, although low-molecular-weight heparins are more specific to factor Xa. When choosing VTE prophylaxis, renal function must be considered. The halflife of the anticoagulant effect of heparin is about 1.5 hours and the dose does not change with renal or hepatic function [57]. On the other hand, low-molecular-weight heparins must be doseadjusted or avoided in patients with renal dysfunction. Enoxaparin exposure, for example, is 
increased by $65 \%$ in patients with severe renal impairment [58]. Dosing should be critically evaluated in patients with low body weight as exposure increases in underweight individuals [59]. Other considerations when choosing pharmacological VTE prophylaxis are drug half-life and planned invasive procedures. The half-life of the commonly used agents are 1.5 hours, 4.5 hours, and 4-5 hours for heparin, enoxaparin and dalteparin, respectively. Some institutions will perform invasive procedures while the patient is on prophylactic doses of anticoagulants, while others recommend holding doses for 4-5 half-lives.

VTE prophylaxis tends to be under used in older adults due to a perceived fear of increased risk of bleeding. However, the benefits of VTE prophylaxis frequently outweigh the risks if appropriate precautions are taken [59]. Risk factors for VTE including older age, prolonged immobility, and indwelling central venous catheters or external ventricular drains are common in ICH patients [46, 60]. Considering the high risk of VTE after ICH, VTE prophylaxis should be started as soon as the hematoma has stabilized; some institutions start as early as 24 hours after the event. Although there is considerable apprehension about starting VTE prophylaxis after $\mathrm{ICH}$, multiple trials have demonstrated that there is no increased risk of hematoma expansion when VTE prophylaxis is initiated within 48 hours [61-63]. Current guidelines recommend initiating mechanical VTE prophylaxis at the time of hospital admission and chemical VTE prophylaxis with unfractionated heparin or low-molecular-weight heparin within 1-4 days of admission in patients with stable hematomas and no evidence of ongoing coagulopathy, but preferentially within 48 hours (Table 8) $[5,54]$. Appropriately dosed for weight and organ function, VTE prophylaxis is recommended in all older adult patients unless a contraindication exists [64].

\section{Summary}

The ideal management of older adults with $\mathrm{ICH}$ aligns with guideline recommendations considering the appropriate representation of older adults in clinical trials used as supporting evidence. Older adults continue to be well represented in $\mathrm{ICH}$ clinical trials and age-specific outcomes should be reported to ascertain if studied treatments are safe and effective in this population. As in all disease states, patient specific factors may alter the treatment course for older adults. Medications should be appropriately chosen and dosed for renal and hepatic dysfunction, and other comorbidities and potential drug-drug interactions should be considered to optimize personalized treatment strategies.

\section{Author Contributions}

MS wrote the first draft of the paper. MS, SA, and GMB revised the manuscript and approve the final version.

\section{Funding}

The contents of this manuscript were developed in part under a grant from the National Institute on Disability, Independent Living, and Rehabilitation Research (NIDILRR grant number 90AR5025). NIDILRR is a Center within the Administration for Community Living (ACL), Department of Health and Human Services (HHS). The contents of this manuscript do not necessarily represent the policy of NIDILRR, ACL, HHS, and you should not assume endorsement by the Federal Government. 


\section{Competing Interests}

Dr. Brophy is a consultant and speaker for Chiesi. Drs. Sandler and Almohaish have no competing interests.

\section{References}

1. Van Asch CJ, Luitse MJ, Rinkel GJ, van der Tweel I, Algra A, Klijn CJ. Incidence, case fatality, and functional outcome of intracerebral haemorrhage over time, according to age, sex, and ethnic origin: A systematic review and meta-analysis. Lancet Neurol. 2010; 9: 167-176.

2. An SJ, Kim TJ, Yoon BW. Epidemiology, risk factors, and clinical features of intracerebral hemorrhage: An update. J Stroke. 2017; 19: 3-10.

3. Chiquete E, Ruiz-Sandoval MC, Álvarez-Palazuelos LE, Padilla-Martínez JJ, González-Cornejo S, Ruiz-Sandoval JL. Hypertensive intracerebral hemorrhage in the very elderly. Cerebrovasc Dis. 2007; 24: 196-201.

4. Kneihsl M, Enzinger C, Niederkorn K, Wünsch G, Müller L, Culea V, et al. Stroke referrals from nursing homes: High rate of mimics and late presentation. Cerebrovasc Dis. 2018; 45: 109-114.

5. HemphillIII JC, Greenberg SM, Anderson CS, Becker K, Bendok BR, Cushman M, et al. Guidelines for the management of spontaneous intracerebral hemorrhage. Stroke. 2015; 46: 2032-2060.

6. Morotti A, Goldstein JN. Anticoagulant-associated intracerebral hemorrhage. Brain Hemorrhages. 2020; 1: 89-94.

7. Inohara T, Xian Y, Liang L, Matsouaka RA, Saver JL, Smith EE, et al. Association of intracerebral hemorrhage among patients taking non-vitamin $\mathrm{K}$ antagonist vs vitamin $\mathrm{K}$ antagonist oral anticoagulants with in-hospital mortality. JAMA. 2018; 319: 463-473.

8. Epple C, Steiner T. Management of oral anticoagulant-associated intracerebral hemorrhage. J Stroke Med. 2018; 1: 114-125.

9. Frontera JA, Lewin III JJ, Rabinstein AA, Aisiku IP, Alexandrov AW, Cook AM, et al. Guideline for reversal of antithrombotics in intracranial hemorrhage. Neurocrit Care. 2016; 24: 6-46.

10. Mayer SA, Brun NC, Begtrup K, Broderick J, Davis S, Diringer MN, et al. Efficacy and safety of recombinant activated factor VII for acute intracerebral hemorrhage. N Engl J Med. 2008; 358: 2127-2137.

11. Diringer MN, Skolnick BE, Mayer SA, Steiner T, Davis SM, Brun NC, et al. Thromboembolic events with recombinant activated factor VII in spontaneous intracerebral hemorrhage: Results from the factor seven for acute hemorrhagic stroke (FAST) trial. Stroke. 2010; 41: 48-53.

12. Steiner T, Poli S, Griebe M, Hüsing J, Hajda J, Freiberger A, et al. Fresh frozen plasma versus prothrombin complex concentrate in patients with intracranial haemorrhage related to vitamin $\mathrm{K}$ antagonists (INCH): A randomised trial. Lancet Neurol. 2016; 15: 566-573.

13. Baharoglu MI, Cordonnier C, Salman RA, De Gans K, Koopman MM, Brand A, et al. Platelet transfusion versus standard care after acute stroke due to spontaneous cerebral haemorrhage associated with antiplatelet therapy (PATCH): A randomised, open-label, phase 3 trial. Lancet. 2016; 387: 2605-2613.

14. Glund S, Stangier J, van Ryn J, Schmohl M, Moschetti V, Haazen W, et al. Effect of age and renal function on idarucizumab pharmacokinetics and idarucizumab-mediated reversal of dabigatran anticoagulant activity in a randomized, double-blind, crossover phase lb study. Clin Pharmacokinet. 2017; 56: 41-54. 
15. Pollack Jr CV, Reilly PA, Van Ryn J, Eikelboom JW, Glund S, Bernstein RA, et al. Idarucizumab for dabigatran reversal-full cohort analysis. N Engl J Med. 2017; 377: 431-441.

16. Sprigg N, Flaherty K, Appleton JP, Salman RA, Bereczki D, Beridze M, et al. Tranexamic acid for hyperacute primary intracerebral haemorrhage ( $\mathrm{TICH}-2)$ : An international randomised, placebocontrolled, phase 3 superiority trial. Lancet. 2018; 391: 2107-2115.

17. Lu VM, Phan K, Rao PJ, Sharma SV, Kasper EM. Dabigatran reversal by idarucizumab in the setting of intracranial hemorrhage: A systematic review of the literature. Clin Neurol Neurosurg. 2019; 181: 76-81.

18. Connolly SJ, Crowther M, Eikelboom JW, Gibson CM, Curnutte JT, Lawrence JH, et al. Full study report of andexanet alfa for bleeding associated with factor Xa inhibitors. N Engl J Med. 2019; 380: 1326-1335.

19. Mengel A, Stefanou MI, Hadaschik KA, Wolf M, Stadler V, Poli K, et al. Early administration of desmopressin and platelet transfusion for reducing hematoma expansion in patients with acute antiplatelet therapy associated intracerebral hemorrhage*. Crit Care Med. 2020; 48: 1009-1017.

20. Saljoughian M. Polypharmacy and drug adherence in elderly patients. US Pharm. 2019; 44: 3336.

21. Li YG, Lip GY. Anticoagulation resumption after intracerebral hemorrhage. Curr Atheroscler Rep. 2018; 20: 1-10.

22. Elsey $R$, Jansen $T$, Lahr $H$, Hellwig $T$. Direct-acting oral anticoagulants for venous thromboembolism in cancer patients. US Pharm. 2015; 40: 7-10.

23. Padrini R. Clinical pharmacokinetics and pharmacodynamics of direct oral anticoagulants in patients with renal failure. Eur J Drug Metab Pharmacokinet. 2019; 44: 1-12.

24. Buckley LF, Rybak E, Aldemerdash A, Cheng JW, Fanikos J. Direct oral anticoagulants in patients with atrial fibrillation and renal impairment, extremes in weight, or advanced age. Clin Cardiol. 2017; 40: 46-52.

25. Refaai MA, Goldstein JN, Lee ML, Durn BL, Milling Jr TJ, Sarode R. Increased risk of volume overload with plasma compared with four-factor prothrombin complex concentrate for urgent vitamin K antagonist reversal. Transfusion. 2015; 55: 2722-2729.

26. Zafar MU, Smith DA, Baber U, Sartori S, Chen K, Lam DW, et al. Impact of timing on the functional recovery achieved with platelet supplementation after treatment with ticagrelor. Circ Cardiovasc Interv. 2017; 10: e005120.

27. Butler K, Teng R. Pharmacokinetics, pharmacodynamics, and safety of ticagrelor in volunteers with mild hepatic impairment. J Clin Pharmacol. 2011; 51: 978-987.

28. Powers WJ, Rabinstein AA, Ackerson T, Adeoye OM, Bambakidis NC, Becker K, et al. Guidelines for the early management of patients with acute ischemic stroke: 2019 update to the 2018 guidelines for the early management of acute ischemic stroke: A guideline for healthcare professionals from the American Heart Association/American Stroke Association. Stroke. 2019; 50: e344-e418.

29. Whelton PK, Carey RM, Aronow WS, Casey DE, Collins KJ, Dennison HC, et al. 2017 ACC/AHA/AAPA/ABC/ACPM/AGS/APhA/ASH/ASPC/NMA/PCNA guideline for the prevention, detection, evaluation, and management of high blood pressure in adults: $A$ report of the American College of Cardiology/American Heart Association Task Force on Clinical practice guidelines. Hypertension. 2018; 71: e13-e115. 
30. Song L, Sandset EC, Arima H, Heeley E, Delcourt C, Chen G, et al. Early blood pressure lowering in patients with intracerebral haemorrhage and prior use of antithrombotic agents: Pooled analysis of the INTERACT studies. J Neurol Neurosurg Psychiatry. 2016; 87: 1330-1335.

31. Qureshi Al, Palesch YY, Barsan WG, Hanley DF, Hsu CY, Martin RL, et al. Intensive blood-pressure lowering in patients with acute cerebral hemorrhage. N Engl J Med. 2016; 375: 1033-1043.

32. Moullaali TJ, Wang X, Martin RH, Shipes VB, Robinson TG, Chalmers J, et al. Blood pressure control and clinical outcomes in acute intracerebral haemorrhage: A preplanned pooled analysis of individual participant data. Lancet Neurol. 2019; 18: 857-864.

33. Lattanzi S, Cagnetti C, Provinciali L, Silvestrini M. How should we lower blood pressure after cerebral hemorrhage? A systematic review and meta-analysis. Cerebrovasc Dis. 2017; 43: 207213.

34. Toyoda K, Koga M, Yamamoto H, Foster L, Palesch YY, Wang Y, et al. Clinical outcomes depending on acute blood pressure after cerebral hemorrhage. Ann Neurol. 2019; 85: 105-113.

35. Qureshi Al, Palesch YY, Foster LD, Barsan WG, Goldstein JN, Hanley DF, et al. Blood pressureattained analysis of ATACH 2 trial. Stroke. 2018; 49: 1412-1418.

36. Anderson CS, Heeley E, Huang Y, Wang J, Stapf C, Delcourt C, et al. Rapid blood-pressure lowering in patients with acute intracerebral hemorrhage. N Engl J Med. 2013; 368: 2355-2365.

37. Krishnan K, Scutt P, Woodhouse L, Adami A, Becker JL, Cala LA, et al. Continuing versus stopping prestroke antihypertensive therapy in acute intracerebral hemorrhage: $A$ subgroup analysis of the efficacy of nitric oxide in stroke trial. J Stroke Cerebrovasc Dis. 2016; 25: 1017-1026.

38. Shi L, Xu S, Zheng J, Xu J, Zhang J. Blood pressure management for acute intracerebral hemorrhage: A meta-analysis. Sci Rep. 2017; 7: 14345.

39. Boulouis G, Morotti A, Goldstein JN, Charidimou A. Intensive blood pressure lowering in patients with acute intracerebral haemorrhage: Clinical outcomes and haemorrhage expansion. Systematic review and meta-analysis of randomised trials. J Neurol Neurosurg Psychiatry. 2017; 88: 339-345.

40. de Havenon A, Majersik JJ, Stoddard G, Wong KH, McNally JS, Smith AG, et al. Increased blood pressure variability contributes to worse outcome after intracerebral hemorrhage: An analysis of ATACH-2. Stroke. 2018; 49: 1981-1984.

41. Divani AA, Liu X, Petersen A, Lattanzi S, Anderson CS, Ziai W, et al. The magnitude of blood pressure reduction predicts poor in-hospital outcome in acute intracerebral hemorrhage. Neurocrit Care. 2020; 33: 389-398.

42. Tanaka E, Koga M, Kobayashi J, Kario K, Kamiyama K, Furui E, et al. Blood pressure variability on antihypertensive therapy in acute intracerebral hemorrhage: The stroke acute management with urgent risk-factor assessment and improvement-intracerebral hemorrhage study. Stroke. 2014; 45: 2275-2279.

43. Manning L, Hirakawa Y, Arima H, Wang X, Chalmers J, Wang J, et al. Blood pressure variability and outcome after acute intracerebral haemorrhage: A post-hoc analysis of INTERACT2, a randomised controlled trial. Lancet Neurol. 2014; 13: 364-373.

44. Qureshi Al, Huang W, Lobanova I, Barsan WG, Hanley DF, Hsu CY, et al. Outcomes of intensive systolic blood pressure reduction in patients with intracerebral hemorrhage and excessively high initial systolic blood pressure: Post hoc analysis of a randomized clinical trial. JAMA Neurol. 2020; 77: 1355-1365. 
45. Lacut K, Le Gal G, Mottier D. Primary prevention of venous thromboembolism in elderly medical patients. Clin Interv Aging. 2008; 3: 399-411.

46. Zeng Z, Hu Z, Zhang J. Venous thromboembolism prevention during the acute phase of intracerebral hemorrhage. J Neurol Sci. 2015; 358: 3-8.

47. CLOTS Trials Collaboration. Effectiveness of thigh-length graduated compression stockings to reduce the risk of deep vein thrombosis after stroke (CLOTS trial 1): A multicentre, randomised controlled trial. Lancet. 2009; 373: 1958-1965.

48. CLOTS (Clots in Legs Or sTockings after Stroke) Trial Collaboration. Thigh-length versus belowknee stockings for deep venous thrombosis prophylaxis after stroke: A randomized trial. Ann Intern Med. 2010; 153 :553-562.

49. Paciaroni M, Agnelli G, Venti M, Alberti A, Acciarresi M, Caso V. Efficacy and safety of anticoagulants in the prevention of venous thromboembolism in patients with acute cerebral hemorrhage: A meta-analysis of controlled studies. J Thromb Haemost. 2011; 9: 893-898.

50. CLOTS (Clots in Legs Or sTockings after Stroke) Trials Collaboration. Effectiveness of intermittent pneumatic compression in reduction of risk of deep vein thrombosis in patients who have had a stroke (CLOTS 3): A multicentre randomised controlled trial. Lancet. 2013; 382: 516-524.

51. Farr S, Toor H, Patchana T, Podkovik S, Wiginton IV JG, Sweiss R, et al. Risks, benefits, and the optimal time to resume deep vein thrombosis prophylaxis in patients with intracranial hemorrhage. Cureus. 2019; 11: e5827.

52. Munoz-Venturelli $P$, Wang $X$, Lavados PM, Stapf $C$, Robinson $T$, Lindley $R$, et al. Prophylactic heparin in acute intracerebral hemorrhage: A propensity score-matched analysis of the INTERACT2 study. Int J Stroke. 2016; 11: 549-556.

53. Shah JN, Murthy SB, Dlugash R, McBee N, Awad I, Hanley DF, et al. Venous thromboembolism after intraventricular hemorrhage: Results from the CLEAR III trial. Neurosurgery. 2019; 84: 709716.

54. Faust AC, Finch CK, Hurdle AC, Elijovich L. Early versus delayed initiation of pharmacological venous thromboembolism prophylaxis after an intracranial hemorrhage. Neurologist. 2017; 22: 166-170.

55. Sprügel MI, Sembill JA, Kuramatsu JB, Gerner ST, Hagen M, Roeder SS, et al. Heparin for prophylaxis of venous thromboembolism in intracerebral haemorrhage. J Neurol Neurosurg Psychiatry. 2019; 90: 783-791.

56. Nyquist P, Bautista C, Jichici D, Burns J, Chhangani S, DeFilippis M, et al. Prophylaxis of venous thrombosis in neurocritical care patients: An evidence-based guideline: A statement for healthcare professionals from the Neurocritical Care Society. Neurocrit Care. 2016; 24: 47-60.

57. DailyMed. HEPARIN SODIUM injection [Internet]. Bethesda, MD: National Library of Medicine; 2020 [cited date 2021 February 3rd]. Available from: https://dailymed.nIm.nih.gov/dailymed/drugInfo.cfm?setid=56dc3074-f1c5-45a3-b923f1d14858e06d.

58. DailyMed. ENOXAPARIN SODIUM injection [Internet]. Bethesda, MD: National Library of Medicine; 2019 [cited date 2021 February 3rd]. Available from: https://dailymed.nlm.nih.gov/dailymed/drugInfo.cfm?setid=bbebb81f-5137-4097-b91f7ee87bd12bcf.

59. Robert-Ebadi H, Le Gal G, Righini M. Use of anticoagulants in elderly patients: Practical recommendations. Clin Interv Aging. 2009; 4: 165-177. 
60. Kim KS, Brophy GM. Symptomatic venous thromboembolism: incidence and risk factors in patients with spontaneous or traumatic intracranial hemorrhage. Neurocrit Care. 2009; 11: 2833.

61. Boeer A, Voth E, Henze TH, Prange HW. Early heparin therapy in patients with spontaneous intracerebral haemorrhage. J Neurol Neurosurg Psychiatry. 1991; 54: 466-467.

62. Kiphuth IC, Staykov D, Köhrmann M, Struffert T, Richter G, Bardutzky J, et al. Early administration of low molecular weight heparin after spontaneous intracerebral hemorrhage. Cerebrovasc Dis. 2009; 27: 146-150.

63. Orken DN, Kenangil G, Ozkurt H, Guner C, Gundogdu L, Basak M, et al. Prevention of deep venous thrombosis and pulmonary embolism in patients with acute intracerebral hemorrhage. Neurologist. 2009; 15: 329-331.

64. Greig MF, Rochow SB, Crilly MA, Mangoni AA. Routine pharmacological venous thromboembolism prophylaxis in frail older hospitalised patients: Where is the evidence? Age Ageing. 2013; 42: 428-434.

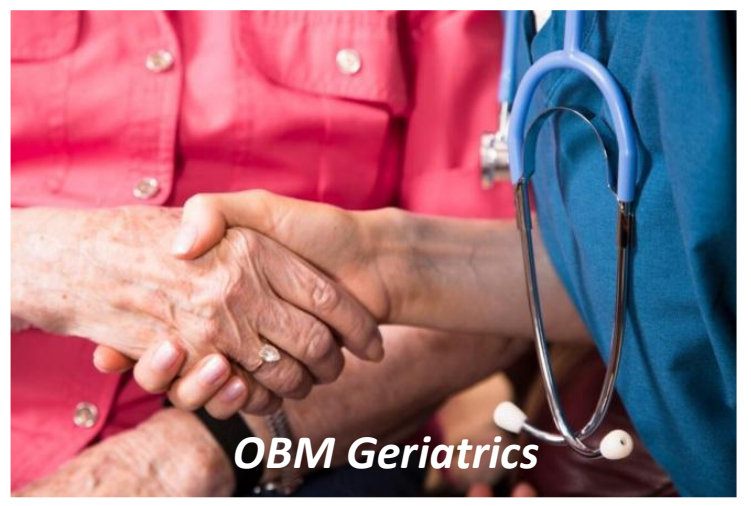

Enjoy OBM Geriatrics by:

1. Submitting a manuscript

2. Joining in volunteer reviewer bank

3. Joining Editorial Board

4. Guest editing a special issue

For more details, please visit: http://www.lidsen.com/journals/geriatrics 